\title{
Predicting Gene Ontology Biological Process From Temporal Gene Expression Patterns
}

\author{
Astrid Lægreid, ${ }^{1,4}$ Torgeir R. Hvidsten, $^{2}$ Herman Midelfart, ${ }^{2}$ Jan Komorowski, ${ }^{2,3,4}$ \\ and Arne K. Sandvik ${ }^{1}$ \\ ${ }^{7}$ Department of Cancer Research and Molecular Medicine, Norwegian University of Science and Technology, N-7489 \\ Trondheim, Norway; ${ }^{2}$ Department of Information and Computer Science, Norwegian University of Science and Technology, \\ N-7491 Trondheim, Norway; ${ }^{3}$ The Linnaeus Centre for Bioinformatics, Uppsala University, SE-751 24 Uppsala, Sweden
}

\begin{abstract}
The aim of the present study was to generate hypotheses on the involvement of uncharacterized genes in biological processes. To this end, supervised learning was used to analyze microarray-derived time-series gene expression data. Our method was objectively evaluated on known genes using cross-validation and provided high-precision Gene Ontology biological process classifications for 211 of the 213 uncharacterized genes in the data set used. In addition, new roles in biological process were hypothesized for known genes. Our method uses biological knowledge expressed by Gene Ontology and generates a rule model associating this knowledge with minimal characteristic features of temporal gene expression profiles. This model allows learning and classification of multiple biological process roles for each gene and can predict participation of genes in a biological process even though the genes of this class exhibit a wide variety of gene expression profiles including inverse coregulation. A considerable number of the hypothesized new roles for known genes were confirmed by literature search. In addition, many biological process roles hypothesized for uncharacterized genes were found to agree with assumptions based on homology information. To our knowledge, a gene classifier of similar scope and functionality has not been reported earlier.
\end{abstract}

[Supplemental material is available online at www.genome.org. All annotations, reclassifications of known genes, and classifications of uncharacterized genes are available online at http:/ / www.lcb.uu.se/ hvidsten / fibroblast.]

One of the main goals of the postgenomic era is to understand the multiple biological roles of genes and gene products, and their interaction in complex networks in living organisms. With the scarce and fragmented status of present knowledge, this is an enormous challenge. It requires substantial new developments in experimental biology and computer science to extract, translate, and integrate experimental observations into functional molecular biological models. DNA-microarray technology (Schena et al. 1995) allows parallel measurement of thousands of genes in different biological settings. Genes coding for gene products involved in the same biological process are likely to be regulated in a coordinated manner. Therefore, when searching for the roles of a gene in terms of involvement in biological processes, measurements of changes in gene expression throughout the time course of a given biological response are of particular interest.

Clustering methods (unsupervised learning) offer efficient ways of finding overall patterns and tendencies in microarray gene expression data. Such methods can discover classes of expression patterns and identify groups of genes that are regulated in a similar manner and can therefore indicate along which lines biological interpretations may be sought in a given experiment (Eisen et al. 1998; Iyer et al. 1999). On the other hand, unsupervised learning methods usually do not use existing biological knowledge in finding

${ }^{4}$ Corresponding authors.

E-MAIL astrid.lagreid@medisin.ntnu; FAX 4773598613. E-MAIL jan.komorowski@Icb.uu.se; FAX 46184716698.

Article and publication are at http://www.genome.org/cgi/doi/10.1101/ gr.1144503. Article published online before print in April 2003. the clusters, and they do not offer well-established methods for classifying uncharacterized genes according to their biological roles. By including biological knowledge in the learning process, supervised methods can generate geneexpression-based models that can be used for classification of unknown genes. Furthermore, such models can be objectively evaluated with respect to classification quality.

Although hierarchical clustering has shown that similarity in biological roles often corresponds to expression similarity (Eisen et al. 1998), biologically related genes in many instances show dissimilar expression profiles and may even be inversely coregulated (Eisen et al. 1998; Iyer et al. 1999; Shatkay et al. 2000; Stanton et al. 2000). Moreover, gene products often have multiple actions. The relations between temporal changes in gene transcript levels and the multiple biological roles of the gene products are so complex that, given our present knowledge, it may only be possible to use learning from examples to create models.

The Gene Ontology (GO) (http://www.geneontology.org; The Gene Ontology Consortium 2000) provides a valuable source of structured knowledge of protein function in terms of molecular function, biological process, and cellular component. In each of these three ontologies, the classifications are arranged in a hierarchy in which the components may have more than one parent component (directed acyclic graph). Use of GO in analysis of experimental data from highthroughput methods enables integration of biological background data in a controlled manner.

Our particular research goal was to model the relationships between gene expression as a function of time and involvement of a gene in a given biological process and to use this model 
Table 1. Annotation of Known Genes

\begin{tabular}{|c|c|c|c|c|}
\hline $\begin{array}{l}\text { Gene } \\
\text { symbol }\end{array}$ & Gene name & $\begin{array}{l}\text { GenBank } \\
\text { accession } \\
\text { number }\end{array}$ & $\begin{array}{l}\text { Annotations at the } \\
\text { most specific level of GO }\end{array}$ & $\begin{array}{l}\text { Annotations to the } \\
23 \text { broad cellular processes } \\
\text { used for learning }\end{array}$ \\
\hline SEPP1 & Selenoprotein P, plasma, 1 & AA045003 & $\begin{array}{l}\text { Oxidative stress response (GO: } \\
\text { 0006979), metal ion transport } \\
(\mathrm{GO} 0006823)\end{array}$ & $\begin{array}{l}\text { Stress response (GO:0006950), } \\
\text { transport (GO:0006810) }\end{array}$ \\
\hline EPB41L2 & $\begin{array}{l}\text { Erythrocyte membrane protein } \\
\text { band } 4.1 \text {-like } 2\end{array}$ & W88572 & $\begin{array}{l}\text { Positive control of cell proliferation } \\
\text { (GO:0008284) }\end{array}$ & Cell proliferation (GO:0008283) \\
\hline OA48-18 & Acid-inducible phosphoprotein & AA029909 & Cell proliferation (GO:0008283) & Cell proliferation (GO:0008283) \\
\hline CTSK & Cathepsin K (pycnodysostosis) & AA044619 & $\begin{array}{l}\text { Proteolysis and peptidolysis (GO: } \\
\text { 0006508) }\end{array}$ & $\begin{array}{l}\text { Protein metabolism and } \\
\text { modification (GO:0006411) }\end{array}$ \\
\hline CPT1B & $\begin{array}{l}\text { Carnitine palmitoyltransferase I, } \\
\text { muscle }\end{array}$ & W89012 & $\begin{array}{l}\text { Fatty acid } \beta \text {-oxidation (GO: } \\
0006635 \text { ) }\end{array}$ & Lipid metabolism (GO:0006629) \\
\hline CLDN11 & $\begin{array}{l}\text { Claudin } 11 \text { (oligodendrocyte } \\
\text { transmembrane protein) }\end{array}$ & N22392 & $\begin{array}{l}\text { Cell adhesion (GO:0007155), } \\
\text { substrate-bound cell migration } \\
\text { (GO:0006929), cell proliferation } \\
\text { (GO:0008283), developmental } \\
\text { processes (GO:0007275) }\end{array}$ & $\begin{array}{l}\text { Cell adhesion (GO:0007155), cell } \\
\text { motility (GO:0006928), cell } \\
\text { proliferation (GO:0008283), } \\
\text { developmental processes (GO: } \\
0007275 \text { ) }\end{array}$ \\
\hline \multirow[t]{3}{*}{ RPL5 } & Ribosomal protein L5 & AA027277 & $\begin{array}{l}\text { Protein biosynthesis (GO: } \\
0006412 \text { ), ribosomal large } \\
\text { subunit assembly and } \\
\text { maintenance (GO:0000027) }\end{array}$ & $\begin{array}{l}\text { Protein metabolism and } \\
\text { modification (GO:0006411), cell } \\
\text { organization and biogenesis } \\
\text { (GO:0006996) }\end{array}$ \\
\hline & $\begin{array}{l}\text { Homo sapiens clone } 23785 \text { mRNA } \\
\text { sequence }\end{array}$ & N32247 & $\begin{array}{l}\text { Calcium-independent cell-cell } \\
\text { matrix adhesion (GO:0007161) }\end{array}$ & Cell adhesion (GO:0007155) \\
\hline & $\begin{array}{l}\text { ESTs, weakly similar to A45082 } \\
\text { neurotrophic receptor ror1 } \\
\text { precursor }(H \text {. sapiens) }\end{array}$ & T62968 & $\begin{array}{l}\text { Transmembrane receptor protein } \\
\text { tyrosine kinase signaling } \\
\text { pathway (GO:0007169) }\end{array}$ & $\begin{array}{l}\text { Cell surface receptor-linked signal } \\
\text { transduction (GO:0007166) }\end{array}$ \\
\hline CCNG1 & Cyclin G1 & R45687 & $\begin{array}{l}\text { Cell cycle control (GO:0000074), } \\
\text { mitotic G2 phase (GO: } \\
\text { 0000085), apoptosis (GO: } \\
0006915), \text { mitosis (GO: } \\
0007067)\end{array}$ & $\begin{array}{l}\text { Cell cycle (GO:0007049), cell } \\
\text { death (GO:0008219) }\end{array}$ \\
\hline CDKN1C & $\begin{array}{l}\text { Cyclin-dependent kinase inhibitor } \\
\text { 1C (p57, Kip2) }\end{array}$ & R81336 & $\begin{array}{l}\text { Cell cycle arrest (GO:0007050), cell } \\
\text { cycle arrest (GO:0007050), } \\
\text { negative control of cell } \\
\text { proliferation (GO:0008285) }\end{array}$ & $\begin{array}{l}\text { Cell cycle (GO:0007049), cell } \\
\text { proliferation (GO:0008283) }\end{array}$ \\
\hline \multirow[t]{2}{*}{ GRA1 } & $\begin{array}{l}\text { Glutamate receptor, ionotropic, } \\
\text { AMPA } 1\end{array}$ & N47974 & $\begin{array}{l}\text { Induction of apoptosis (GO: } \\
0006917) \text {, cell surface receptor } \\
\text { linked signal transduction (GO: } \\
0007166 \text { ) }\end{array}$ & $\begin{array}{l}\text { Cell death (GO:0008219), cell } \\
\text { surface receptor-linked signal } \\
\text { transduction (GO:0007166) }\end{array}$ \\
\hline & $\begin{array}{l}\text { Homo sapiens mRNA for KIAA1888 } \\
\text { protein, partial cds }\end{array}$ & H26264 & Transport (GO:0006810) & Transport (GO:0006810) \\
\hline$F M O D$ & Fibromodulin & AA029408 & $\begin{array}{l}\text { Cell-cell matrix adhesion (GO: } \\
0007160 \text { ) }\end{array}$ & Cell adhesion (GO:0007155) \\
\hline$C D K 5 R 1$ & $\begin{array}{l}\text { Cyclin-dependent kinase } 5, \\
\text { regulatory subunit } 1(\mathrm{p} 35)\end{array}$ & R49183 & $\begin{array}{l}\text { Cell proliferation (GO:0008283), } \\
\text { cell cycle control (GO:0000074) }\end{array}$ & $\begin{array}{l}\text { Cell proliferation (GO:0008283), } \\
\text { cell cycle (GO:0007049) }\end{array}$ \\
\hline \multirow[t]{3}{*}{ CAT } & Catalase & W89002 & $\begin{array}{l}\text { Oxidative stress response (GO: } \\
\text { 0006979), peroxidase reaction } \\
\text { (GO:0006804) }\end{array}$ & Stress response (GO:0006950) \\
\hline & $\begin{array}{l}\text { Homo sapiens, clone MGC: } 16131 \\
\text { IMAGE: } 3628944, \text { mRNA, } \\
\text { complete cds }\end{array}$ & R71462 & $\begin{array}{l}\text { Transport (GO:0006810), } \\
\text { intracellular signaling cascade } \\
\text { (GO:0007242) }\end{array}$ & $\begin{array}{l}\text { Transport (GO:0006810), } \\
\text { intracellular signaling cascade } \\
\text { (GO:0007242) }\end{array}$ \\
\hline & $\begin{array}{l}\text { ESTs, moderately similar to JX0336 } \\
\text { succinate dehydrogenase } \\
\text { (H. sapiens) }\end{array}$ & R60996 & $\begin{array}{l}\text { Tricarboxylic acid cycle (GO: } \\
\text { 0006099), fatty acid metabolism } \\
\text { (GO:0006631) }\end{array}$ & $\begin{array}{l}\text { Energy pathways (GO:0006091), } \\
\text { lipid metabolism (GO:0006629) }\end{array}$ \\
\hline
\end{tabular}

Annotations for some of the genes in the data set are shown. A full record of annotations for all known genes is provided in Supplemental Material (available online at http://www.genome.org).

to predict the biological roles of unknown genes. We built an if-then rule model using a supervised learning method based on Rough Sets (Pawlak 1991; Komorowski 1999; Skowron et al. 2002). It associated Gene Ontology (GO) classes of biological processes (The Gene Ontology Consortium 2000) with minimal features of temporal gene transcript profiles from the fibroblast serum response in a data set provided by Iyer et al. (1999). Gene profiles of 497 unknown and known genes in the fibroblast serum response were then subjected to the model to classify (reclassify, respectively) the genes. The process provided hypotheses about multiple roles of the genes in terms of GO biological process. Our method generated a highprecision model that produced a substantial number of new hypotheses about biological roles of both characterized and uncharacterized genes. Methods like the one presented here may be pivotal in future research by permitting a more focused experimental approach to elucidate the biological roles of genes.

\section{Genome Research}


Table 2. Summary of the Rule Model

\begin{tabular}{|c|c|c|c|}
\hline \multicolumn{4}{|c|}{ A. Annotations, rules, and classifications } \\
\hline \multicolumn{4}{|l|}{ Annotated genes } \\
\hline Within the 23 broad & O biological proce & & 273 \\
\hline \multicolumn{4}{|c|}{ Gene probes } \\
\hline \multicolumn{4}{|c|}{ Associated with the 273 genes within the 23 broad biological process classes } \\
\hline \multicolumn{4}{|c|}{ Training examples } \\
\hline \multicolumn{3}{|c|}{ Annotations associated with the genes in the 23 broad biological process classes } & 549 \\
\hline Coannotations $s^{\mathrm{a}}$ assoc & the genes in the 2 & logical process classes & 444 \\
\hline \multicolumn{4}{|c|}{ Rules } \\
\hline \multicolumn{3}{|c|}{ Generated from the training examples } & 18064 \\
\hline \multicolumn{4}{|c|}{ Estimated quality of classifications of unknown genes (cross-validation estimates) } \\
\hline \multicolumn{3}{|l|}{ Sensitivity } & $84 \%$ \\
\hline \multicolumn{3}{|l|}{ Specificity } & $91 \%$ \\
\hline \multirow{2}{*}{\multicolumn{4}{|c|}{$\begin{array}{l}\text { Fraction of classifications that are correct } \\
\text { Classifications for unknown (uncharacterized) genes }\end{array}$}} \\
\hline & & & \\
\hline \multicolumn{3}{|c|}{ Classifications were obtained for 211 of the 213 unknown genes } & 548 \\
\hline \multicolumn{3}{|c|}{ Reclassifications for training examples } & 728 \\
\hline \multicolumn{3}{|c|}{ True positive classifications } & 519 \\
\hline \multicolumn{3}{|c|}{ True positive coclassifications ${ }^{\mathrm{b}}$} & 356 \\
\hline \multicolumn{3}{|c|}{ False positive classifications } & 219 \\
\hline \multirow{2}{*}{\multicolumn{4}{|c|}{$\begin{array}{l}\text { False negative (missing) classifications } \\
\text { For } 272 \text { of the } 273 \text { training examples at least one correct reclassification was obtained }\end{array}$}} \\
\hline & & & \\
\hline \multicolumn{4}{|c|}{ B. Number of biological processes annotated or classified per gene } \\
\hline $\begin{array}{l}\text { Number of biological } \\
\text { processes per gene }\end{array}$ & $\begin{array}{l}\text { Annotations } \\
\text { for training } \\
\text { example genes }\end{array}$ & $\begin{array}{l}\text { Reclassifications } \\
\text { for training } \\
\text { example genes }\end{array}$ & $\begin{array}{l}\text { Classifications for } \\
\text { unknown genes }\end{array}$ \\
\hline 1 & 105 & 30 & 27 \\
\hline 2 & 100 & 93 & 84 \\
\hline 3 & 41 & 96 & 59 \\
\hline$\geq 4$ & 27 & 54 & 41 \\
\hline
\end{tabular}

\section{RESULTS}

\section{Construction of Training Examples}

We used a data set provided by Iyer et al. (1999; http:// genome-www.stanford.edu/serum) that describes the transcript levels of genes detected by 517 different gene probes during the first $24 \mathrm{~h}$ of the serum response in serum-starved human fibroblasts. The 517 gene probes corresponded to 497 unique genes, because 20 genes were represented by more than one probe according to Unigene clustering of cDNA sequences (http://www.ncbi.nlm.nih.gov/UniGene/index. html; 2002). For each gene, biological processes were assigned at the lowest possible (most specific) level of GO (The Gene Ontology Consortium 2000; http://www.geneontology.org/). Information for annotations was extracted manually from UniGene (http://www.ncbi.nlm.nih.gov/UniGene/index. html), LocusLink (http://www.ncbi.nlm.nih.gov/LocusLink/ index.html), SWISS-PROT (http://us.expasy.org/sprot), GENATLAS (http://bisance.citi2.fr/GENATLAS), and from the literature. For 284 of the 497 genes, information for GO annotations was found (Table 1 ). No biological process information was found on the biological roles of the remaining 213 genes, and these were termed unknown or uncharacterized. After the completion of our annotation work, human gene GO annotations have been made available by LocusLink. There is good agreement between our annotations and those at LocusLink. However, in general, we obtained a higher number of annotations per gene, and many of our annotations were at a more detailed level.

The annotated genes formed learning examples from which a rule model was trained. Because supervised learning requires a nontrivial number of examples from each class from which to learn, the genes were grouped into classes of at least 4 elements. To achieve this, the more specific annotations were moved upward in the ontology so that the learning examples were grouped into 23 broad classes of biological processes (e.g., stress response, transport, cell proliferation; see Table 1). Thus, a class is a set of genes that all have an annotation with a common ancestor in the GO hierarchy. Of the 284 known genes, 273 belonged to these 23 broad classes of GO biological process.

The 273 genes of the 23 broad GO classes gave rise to 549 training examples because for 167 genes more than one biological process was annotated to the same gene (see Table $2 \mathrm{~B}$ ). There are several reasons for this coannotation. One reason is that some biological processes have more than one parent in the GO hierarchy. For instance, DNA replication is a child of both DNA metabolism and of cell cycle. Moreover, many of the encoded proteins have multiple biological roles, like ribosomal proteins, which are involved in protein synthesis (process: protein metabolism and modification) as well as being structural components of ribosomes (process: cell organization and biogenesis; see, e.g., RPL5 in Table 1). Another example is cell adhesion proteins, which are often found also to play a role in 

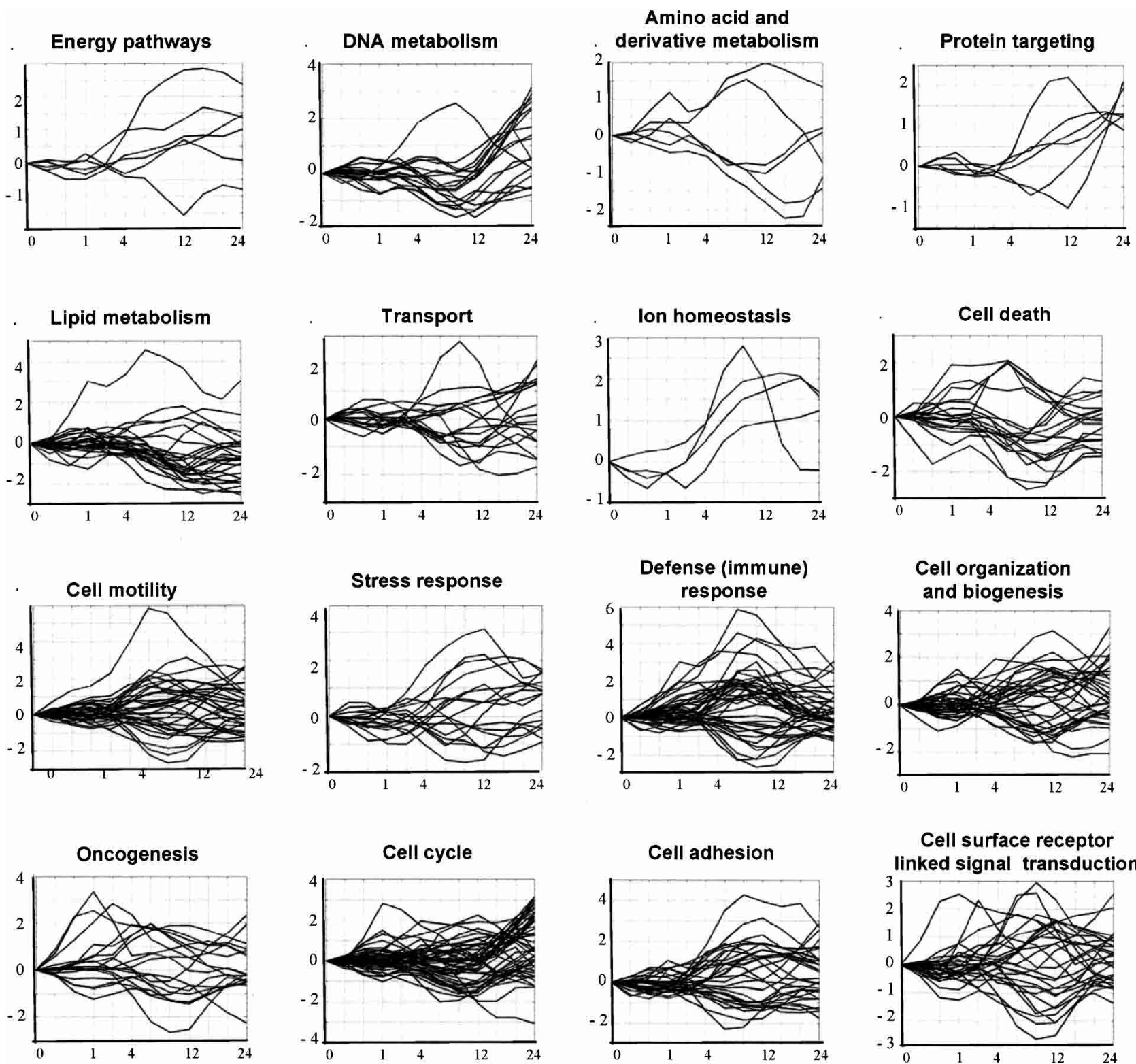

Cell surface receptor linked signal transduction

Intracellular signaling cascade

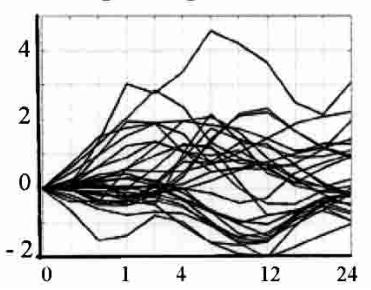

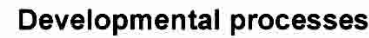

Blood coagulation

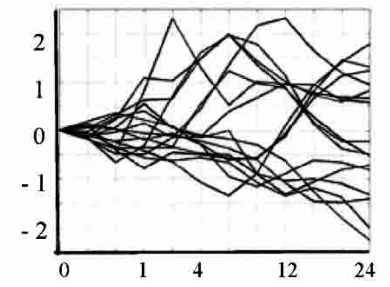

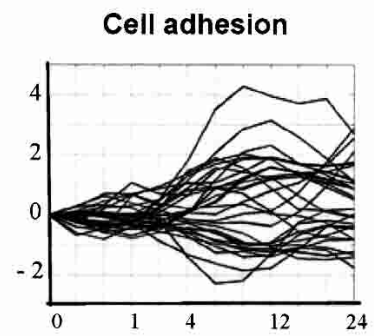

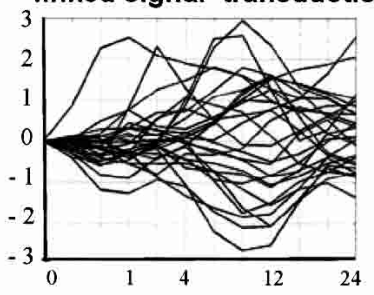

Circulation

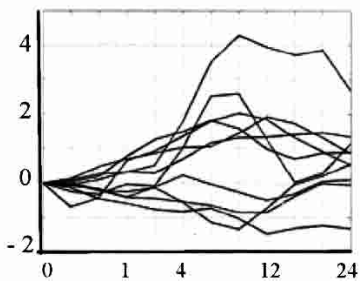

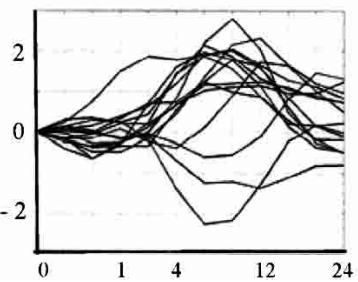

Figure 1 Expression profiles for different biological process function-class training example genes. The $x$-axis shows time, and the $y$-axis shows $\log _{2}$-transformed gene expression ratios (serum treated vs. control). Expression profiles for the three processes not shown in this figure are shown in Figure 3A.

cell motility, cell proliferation, and development (e.g., CLDN11 in Table 1). Furthermore, one type of molecular function may have two or more different descriptions at the biological process level in GO. For example, kinases and phosphatases involved in intracellular signaling cascade are coannotated with protein metabolism and modification because they 


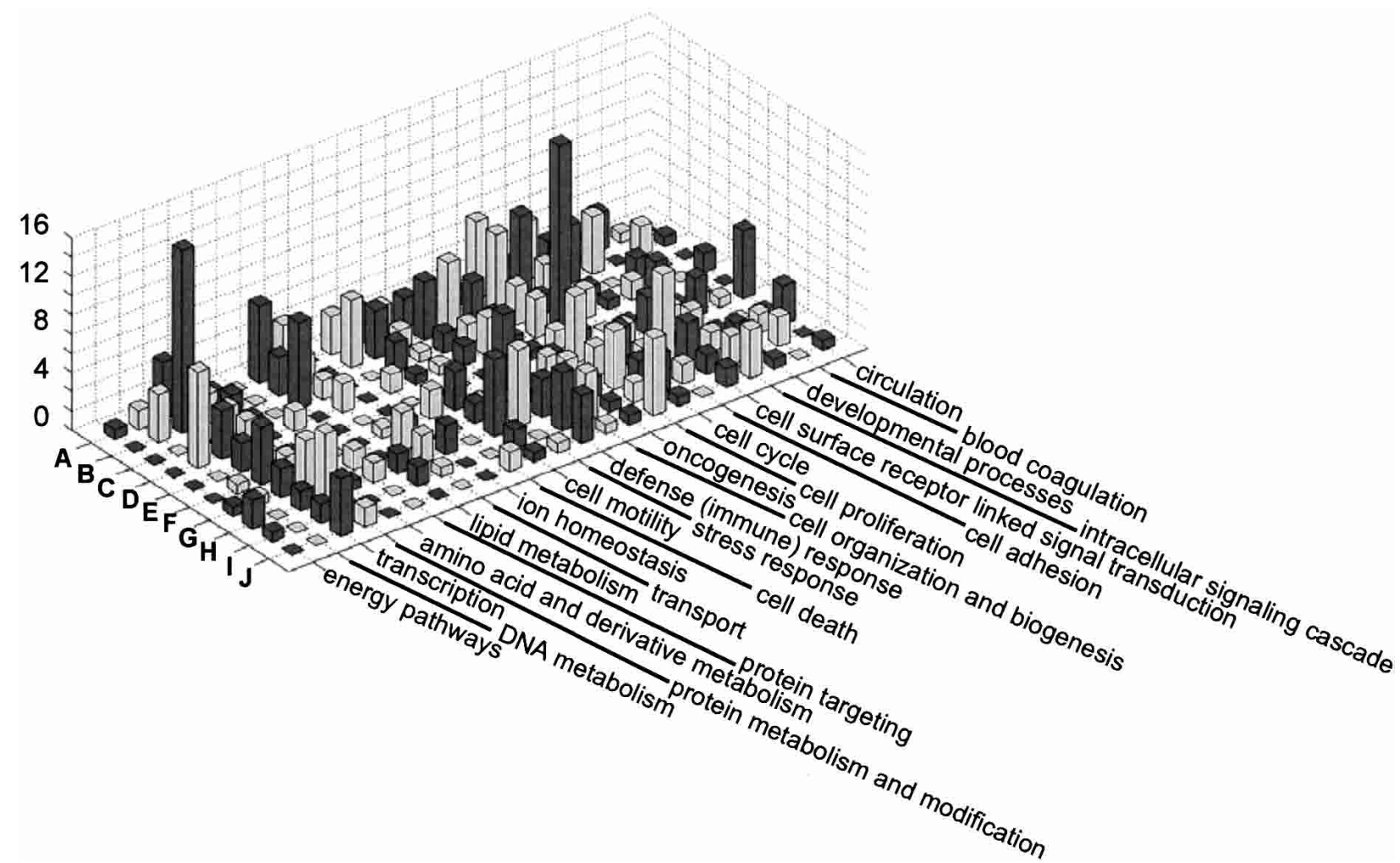

Figure 2 Distribution of training example genes annotated with different biological processes across expression profile clusters. Genes annotated with the 23 broad biological processes used in the present work distributed across the 10 expression profile clusters (A-J) as determined by lyer et al. (1999) using hierarchical clustering.

modify other proteins by phosphorylation and dephosphorylation.

The temporal expression profiles of the genes in each GO class are shown in Figure 1 and Figure 3 below. It can be seen that many of the biological processes involve genes that are up-regulated when other genes involved in the same process are down-regulated. These genes can be said to be inversely coregulated (see, e.g., cell motility and defense (immune) response in Fig. 1). By using agglomerative hierarchical clustering, Iyer et al. (1999) detected 10 major gene expression profile clusters (A-J) among the differentially expressed genes of the serum response. Figure 2 shows that three biological process classes (cell proliferation, protein metabolism and modification, and oncogenesis) contain genes whose expression profiles are distributed among all the 10 expression profile clusters. Another 6 processes included genes with expression profiles distributed among 9 of the 10 expression profile clusters. This observation points out the high complexity of the expression profiles of genes participating in one biological process.

\section{Generating the Rule Model}

A Rough Set-based supervised learning method (Pawlak 1991; Komorowski 1999; Skowron et al. 2002) was used to generate the model from the 549 training examples represented by their GO biological process annotations and by their gene expression levels. To accommodate the high complexity of the temporal gene expression profiles observed for genes in one biological process class (see Figs. 1 and 3), numerical gene expression data were transformed into template data in which each gene expression profile was described as a combination of templates "increase", "decrease", and "constant" over time intervals of at least 3 or 4 time points. The combination of templates and time intervals created 55 different features. Because of this relatively large number, most genes had a unique combination of the 55 features. The template approach allows us to focus on the relative changes in transcript levels and to regard the temporal expression profile of each gene as a combination of several subinterval profiles. Thus, we can discover similarities of changes in transcript levels within shorter time frames than the whole $24-\mathrm{h}$ period.

The trained model defines relationships between the gene expression profiles observed during the fibroblast response (measured data) and the involvement of the genes in GO biological processes (biological background knowledge). It consisted of 18,064 rules and is summarized in Table 2 . The if-then rules of the model that define a particular biological process (see examples in Table 3) describe minimal expression profile properties (features) that discern genes participating in one process from genes participating in all other processes. On the average, 3 out of 55 original features were used in each rule. This shows that minimization effectively removed the insignificant features to obtain general rules that can classify unseen gene profiles. The rules are approximate and define the relationship between gene expression and biological role only with some confidence level. Comparing the transcription gene rule examples in Table 3 with the transcription gene expression profiles in Figure 3A shows that the variety of profiles is much greater than described by the rules in Table 3 . The few rules shown in Table 3 are far from sufficient to completely describe the relationships between expression profiles and the 


\section{Transcription}

A - Annotated genes

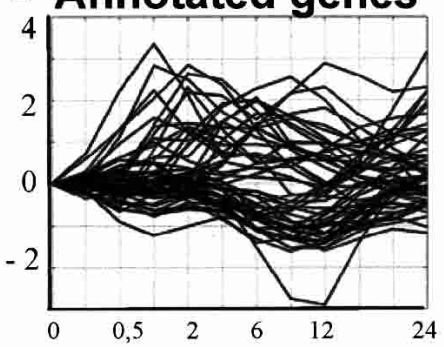

B - True positives

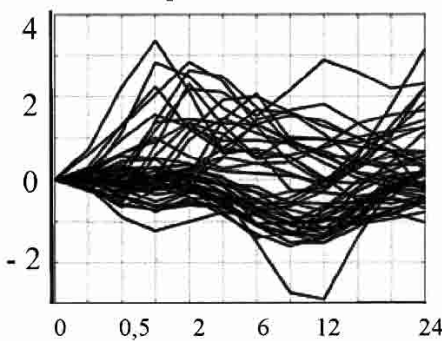

C - False positives

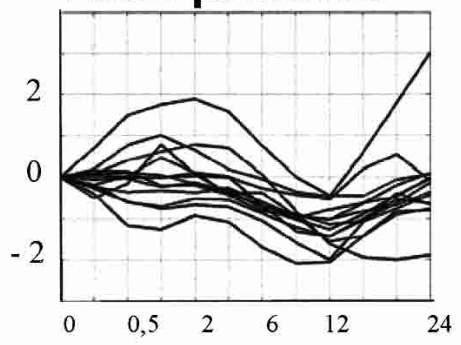

Protein metabolism and modification
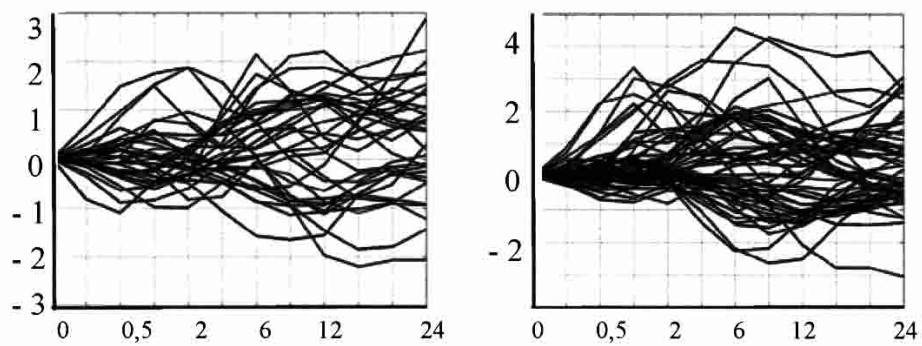

Cell proliferation
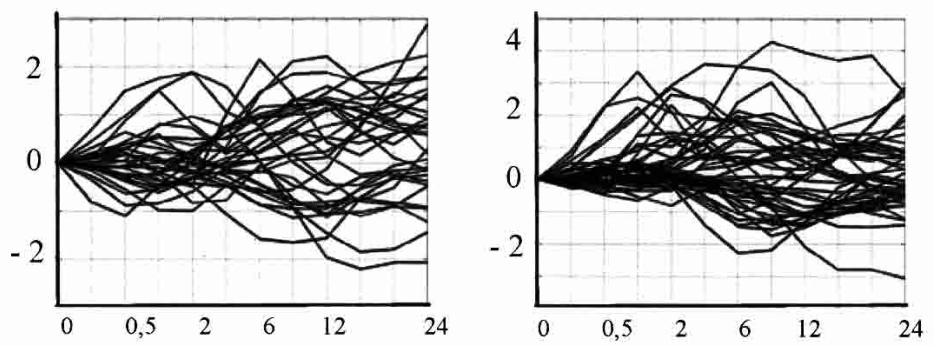
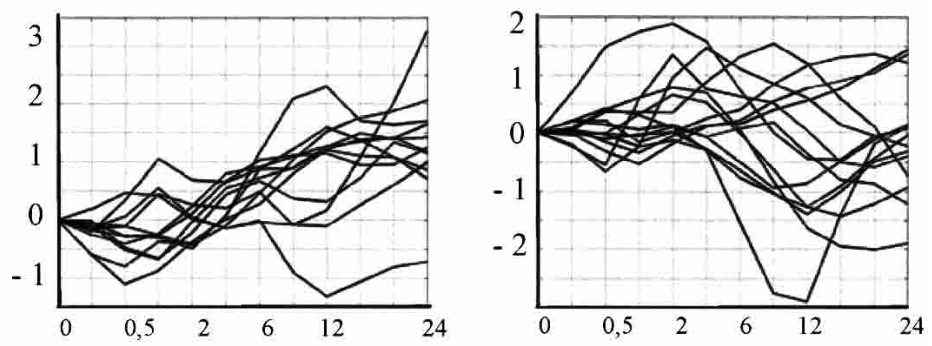

\section{D - False negatives}
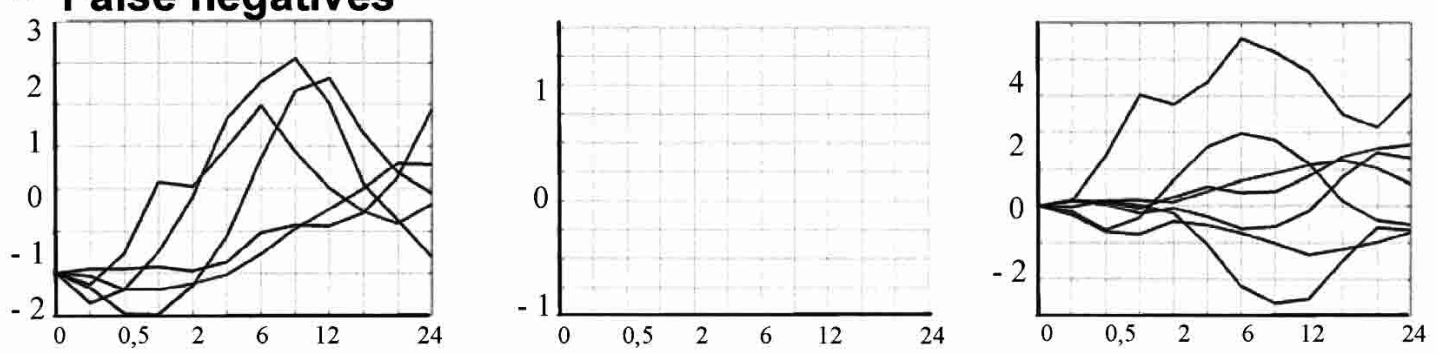

\section{E - Unknown genes}
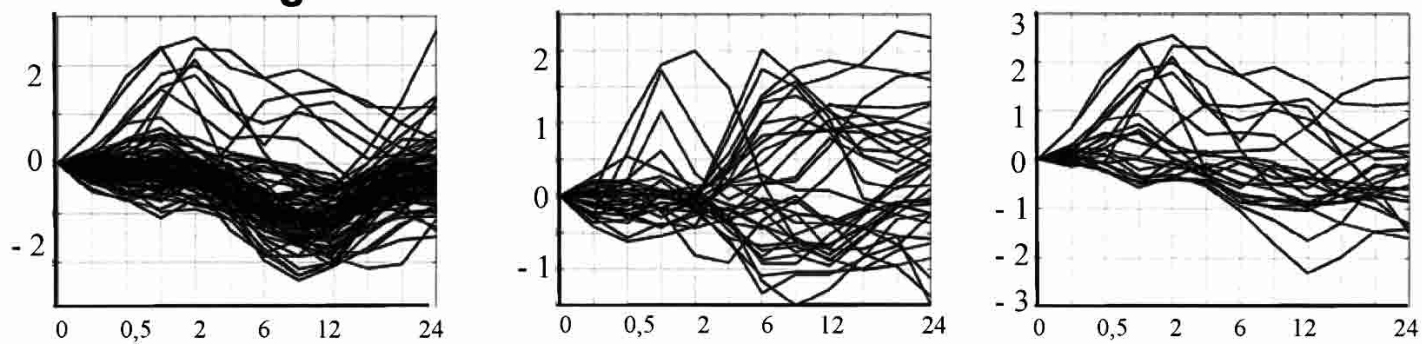

Figure 3 Expression profiles of annotated and classified genes for the processes transcription, protein metabolism and modification, and cell proliferation. The $x$-axis shows time, and the $y$-axis shows $\log _{2}$-transformed gene expression ratios (serum treated vs. control). For each process the following expression profiles are shown: $(A)$ training example genes annotated with the process; $(B)$ training example genes correctly classified to the process, that is, true positives; $(C)$ training example genes classified but not annotated to the process, that is, false positives; $(D)$ training example genes that the rule model failed to classify with the biological process to which they were annotated, that is, false negatives; and (E) unknown (uncharacterized) genes classified to the process. 
Table 3. Examples of Rules Induced for transcription

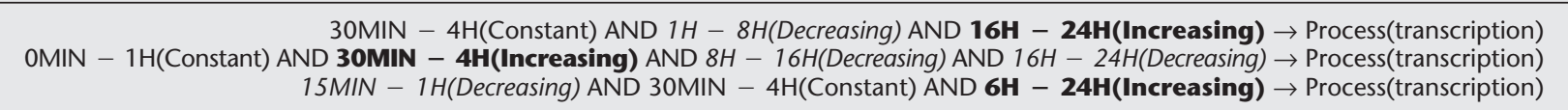

A total of 5402 rules was generated for transcription. Using Michaelski's rule quality measure (Torgo 1993), we selected rules that cover the highest number of genes encoding proteins involved in transcription (cf. coverage) and that exhibit the highest ability to discern these genes from genes involved in all other processes (cf. accuracy). The rules originate from the known genes PBX3, ZNF222, and TRIP7, respectively. The first two rules also participated in the classification of unknown genes KIAA1799 and MGC5469, although only KIAA1799 received a fraction of votes high enough to be classified as transcription.

The three rules shown in the Table had a Michalski's value of $0.75(\mu \times$ accuracy $+(1-\mu) \times$ coverage; where $\mu=0.5+0.25 \times$ accuracy) There was a total of 50 rules for transcription with Michalski's value 0.75 . Intervals where gene expression profiles fit the template for "increasing" are shown in bold letters, whereas intervals that fit the template for "decreasing" are shown in italics (for a description of "increasing/decreasing" templates see Methods).

biological role of transcription genes. A high number of rules (for transcription there were 5402 rules) is needed to define these relationships.

Classifications produced by the model are a direct consequence of the rules. However, only the rules that match the gene to be classified contribute to the classification. For example, the first rule in Table 3 is only used when confronted with an expression profile that meets the requirement of constant transcript levels from $30 \mathrm{~min}$ to $4 \mathrm{~h}$, decreasing levels from $1-8 \mathrm{~h}$, and increasing levels from $16-24 \mathrm{~h}$. The final classifications are then sorted out among all the processes indicated by all the rules matching the gene using a voting procedure (see Methods for details).

A 10-fold cross-validation showed that the model exhibited high classification quality (average AUC value 0.88 ; Table 4). This demonstrates that our model captures the complexity of expression profiles among genes participating in one biological process, and that it is able to apply it successfully in the classification process. The values for sensitivity and specificity were chosen to allow for a high number of true positives at the price of a relatively large number of false positives. With a sensitivity of $84 \%$ (Table 4 ), $49 \%$ of the classifications during crossvalidation were correct. A proportion of correct classifications of $90 \%$ can be achieved by using stricter requirements, but this will result in a decrease in sensitivity to $39 \%$ (data not shown). This illustrates how the predictive model can be adjusted to fit the goals of the analysis with respect to specificity and sensitivity.

\section{Using the Model to Reclassify Known Genes}

We used a model trained from all the example genes to classify unknown genes and to reclassify the known genes (Table 5). This model was trained with the parameters used during cross-validation shown in Table 4. By this approach, the classification quality from cross-validation is normally interpreted as the expected quality of the classifications of uncharacterized genes (unseen cases). The ability of the rule model to recognize and reconstruct the complex expression profiles for genes participating in one biological process is illustrated with an analysis of three sample processes: cell proliferation, transcription, and protein metabolism and modification (Fig. 3). The expression profiles of the correctly classified genes (Fig. 3B) reflect a very broad range of different expression profiles within the annotated genes of one biological process (Fig. 3A).

By reclassification of the annotated genes (Table 6), we obtained one or more correct classifications for 272 of the 273 known genes. Of the total of 738 classifications, 519 (70\%) agreed with the annotations. Reclassification hence generated 219 false-positive classifications, that is, classifications of
Table 4. Classification Quality During Cross-Validation

\begin{tabular}{lcccc}
\hline Process & AUC & SE & Sensitivity & Specificity \\
\hline lon homeostasis & 1.00 & 0.00 & 1.00 & 1.00 \\
Protein targeting & 0.99 & 0.03 & 1.00 & 0.98 \\
Blood coagulation & 0.96 & 0.08 & 0.96 & 0.99 \\
DNA metabolism & 0.94 & 0.09 & 0.94 & 0.93 \\
Intracellular signaling cascade & 0.94 & 0.06 & 0.92 & 0.94 \\
Energy pathways & 0.93 & 0.12 & 0.89 & 0.99 \\
Cell cycle & 0.93 & 0.04 & 0.93 & 0.86 \\
Oncogenesis & 0.92 & 0.11 & 0.94 & 0.93 \\
Circulation & 0.91 & 0.11 & 0.87 & 0.95 \\
Cell death & 0.90 & 0.10 & 0.85 & 0.90 \\
Developmental processes & 0.90 & 0.07 & 0.91 & 0.90 \\
Transcription & 0.88 & 0.11 & 0.84 & 0.82 \\
Defense (immune) response & 0.88 & 0.05 & 0.88 & 0.91 \\
Cell adhesion & 0.87 & 0.09 & 0.85 & 0.91 \\
Stress response & 0.86 & 0.15 & 0.87 & 0.89 \\
Protein metabolism and modification & 0.85 & 0.10 & 0.83 & 0.86 \\
Cell motility & 0.84 & 0.11 & 0.83 & 0.89 \\
Cell surface receptor-linked signal transduction & 0.82 & 0.15 & 0.79 & 0.84 \\
Lipid metabolism & 0.81 & 0.14 & 0.77 & 0.85 \\
Transport & 0.79 & 0.17 & 0.72 & 0.84 \\
Cell organization and biogenesis & 0.79 & 0.11 & 0.76 & 0.91 \\
Cell proliferation & 0.79 & 0.06 & 0.76 & 0.77 \\
Amino acid and derivative metabolism & 0.69 & 0.06 & 0.29 & 0.98 \\
Average & 0.88 & 0.09 & 0.84 & 0.91 \\
\hline
\end{tabular}

Tenfold cross-validation estimates of the area under the ROC curve (AUC), standard error (SE) for AUC, and sensitivity and specificity for each of the 23 biological processes. Sensitivity is TP/(TP + FN) where TP (true positives) is the number of genes classified and annotated to the process and FN (false negatives) is the number of genes annotated but not classified to it. Specificity is TN/(TN + FP), where TN (true negatives) is the number of genes neither annotated nor classified to the process and FP (false positives) is the number of genes classified but not annotated to it. 
Table 5. Classifications Obtained With the Model

\begin{tabular}{|c|c|c|c|}
\hline Process & $\begin{array}{l}\text { Annotate } \\
\text { genes }\end{array}$ & $\begin{array}{l}\text { Reclassifications for } \\
\text { known genes (correct) }\end{array}$ & $\begin{array}{l}\text { Classifications for } \\
\text { unknown genes }\end{array}$ \\
\hline Ion homeostasis & 4 & $4(4)$ & 4 \\
\hline Protein targeting & 6 & $8(6)$ & 2 \\
\hline Blood coagulation & 10 & $13(10)$ & 34 \\
\hline DNA metabolism & 19 & 33 (19) & 28 \\
\hline Intracellular signaling cascade & 26 & $39(25)$ & 14 \\
\hline Energy pathways & 6 & $6(6)$ & 0 \\
\hline Cell cycle & 47 & $66(44)$ & 38 \\
\hline Oncogenesis & 17 & $41(17)$ & 31 \\
\hline Circulation & 15 & $17(15)$ & 3 \\
\hline Cell death & 16 & $22(16)$ & 26 \\
\hline Developmental processes & 15 & $23(15)$ & 21 \\
\hline Transcription & 52 & $61(47)$ & 88 \\
\hline Defense (immune) response & 37 & $44(32)$ & 20 \\
\hline Cell adhesion & 30 & $32(29)$ & 19 \\
\hline Stress response & 17 & $26(17)$ & 22 \\
\hline Protein metabolism and modification & 33 & $45(33)$ & 35 \\
\hline Cell motility & 32 & $40(29)$ & 21 \\
\hline Cell surface receptor linked signal transduction & 27 & $38(26)$ & 34 \\
\hline Lipid metabolism & 26 & $44(25)$ & 45 \\
\hline Transport & 22 & $30(22)$ & 19 \\
\hline Cell organization and biogenesis & 33 & $40(30)$ & 13 \\
\hline Cell proliferation & 53 & $60(46)$ & 30 \\
\hline Amino acid and derivative metabolism & 6 & $6(6)$ & 2 \\
\hline
\end{tabular}

genes to classes with which they were not annotated. Some of these classifications will appear to be incorrect. However, a share of the false-positive classifications may represent new knowledge in the sense that this knowledge may have been unrecognized during the annotation process (i.e., missing annotations). In other instances, the involvement of a gene in the classified biological processes may not have been reported at the time of annotation. In the latter case, we hypothesized new biological roles of known genes.

An examination of the literature for false-positive reclassifications of training examples showed that some of them, indeed, represent existing knowledge. Examples of such missing annotations will be given in the sequel. Of the 14 genes with a false-positive classification for DNA metabolism, 4 were found to participate in this process. These genes are CCNA2 (cyclin A2; Ravnik and Wolgemuth 1996), CENPF (Centromere protein F; Zhu et al. 1995), CKS2 (CDC28 protein kinase 2; Zhang et al. 1995), and XPO1 (Exportin 1), which is a homolog of the yeast CRM1 gene involved in chromosome maintenance (Adachi and Yanagida 1989). Another process with a high proportion of false-positive classifications was oncogenesis. All 17 genes annotated with this process were correctly classified. However, our model predicted that another 24 genes participate in oncogenesis. A literature search revealed that 12 of these 24 false-positive classifications represented missing annotations (Table 7). The genes with missing annotations for oncogenesis include the tumor suppressors CDKN1C (cyclin-dependent kinase inhibitor 1C), EGR1 (early growth response 1), and proto-oncogenes $N R 4 A 3$ (nuclear receptor subfamily 4, group A, member 3 ) and COPEB (core promoter element binding protein). This result shows that the model was able to hypothesize (or to rediscover) existing knowledge that was not included in the initial annotation process.

False-negative classifications are annotations of known genes that our model failed to reproduce as classifications.
This means that the expression profiles of the genes could not be matched to the training examples of the annotated biological process. Examples of such expression profiles are shown in Figure 3D. False negatives may arise from (1) incorrect annotations, (2) insufficient representative learning examples, or (3) no involvement of the genes in question in the annotated biological process in the specific context of the fibroblast serum response. For cell proliferation, there were seven false negatives, including genes correctly classified to participate in cell death (KIT, BMP1) and circulation (BMP1, $V E G F)$. Although these gene products may participate in cell proliferation in other biological responses or in other cell types, they need not be involved in this biological process during the fibroblast serum response.

\section{Coclassification Reveals Coregulation of Biological Processes}

Biological processes occurring during the fibroblast serum response may be related in the sense that genes participating in these processes are transcriptionally coregulated. Coregulation may be discovered by our model by coclassifications of more than one process to the same gene. These coclassifications were generated wherever the model identified a similarity of the expression profile of the classified gene with the profiles of training example genes of two or more different biological processes. High frequencies of coclassifications were obtained for some pairs of processes during reclassification (Table 8), indicating that many training genes from these pairs of processes display similar temporal expression profiles. Our model therefore hypothesized that some biological processes are related via transcriptional coregulation during the fibroblast serum response. Many such pairs of processes, for example, DNA metabolism-cell cycle, cell organization and biogenesis-cell cycle, and cell motility-defense (immune) response, 
Table 6. Reclassification of Known Genes

\begin{tabular}{|c|c|c|c|c|}
\hline $\begin{array}{l}\text { Gene } \\
\text { symbol }\end{array}$ & Gene name & $\begin{array}{l}\text { GenBank } \\
\text { accession } \\
\text { number }\end{array}$ & $\begin{array}{l}\text { Predictions for the } \\
23 \text { broad cellular processes } \\
\text { used for learning }\end{array}$ & $\begin{array}{l}\text { Annotations to the } \\
23 \text { broad cellular processes } \\
\text { used for learning }\end{array}$ \\
\hline SEPP1 & Selenoprotein $\mathrm{P}$, plasma, 1 & AA045003 & Transport, stress response & Stress response, transport \\
\hline EPB4 1L2 & $\begin{array}{l}\text { Erythrocyte membrane protein } \\
\text { band } 4.1 \text {-like } 2\end{array}$ & W88572 & Cell proliferation & Cell proliferation \\
\hline OA48-18 & Acid-inducible phosphoprotein & AA029909 & Cell proliferation & Cell proliferation \\
\hline CTSK & Cathepsin K (pycnodysostosis) & AA044619 & $\begin{array}{l}\text { Cell proliferation, protein } \\
\text { metabolism and modification }\end{array}$ & $\begin{array}{l}\text { Protein metabolism and } \\
\text { modification }\end{array}$ \\
\hline CPT1B & $\begin{array}{l}\text { Carnitine palmitoyltransferase I, } \\
\text { muscle }\end{array}$ & W89012 & Lipid metabolism & Lipid metabolism \\
\hline CLDN11 & $\begin{array}{l}\text { Claudin } 11 \text { (oligodendrocyte } \\
\text { transmembrane protein) }\end{array}$ & N22392 & $\begin{array}{l}\text { Cell proliferation, cell motility, cell } \\
\text { adhesion, developmental } \\
\text { processes }\end{array}$ & $\begin{array}{l}\text { Cell adhesion, cell motility, cell } \\
\text { proliferation, developmental } \\
\text { processes }\end{array}$ \\
\hline \multirow[t]{3}{*}{ RPL5 } & Ribosomal protein L5 & AA027277 & $\begin{array}{l}\text { Protein metabolism and } \\
\text { modification, cell organization } \\
\text { and biogenesis }\end{array}$ & $\begin{array}{l}\text { Protein metabolism and } \\
\text { modification, cell } \\
\text { organization and biogenesis }\end{array}$ \\
\hline & $\begin{array}{l}\text { Homo sapiens clone } 23785 \text { mRNA } \\
\text { sequence }\end{array}$ & N32247 & $\begin{array}{l}\text { Lipid metabolism, cell adhesion, } \\
\text { developmental processes }\end{array}$ & Cell adhesion \\
\hline & $\begin{array}{l}\text { ESTs, weakly similar to A45082 } \\
\text { neurotrophic receptor ror } 1 \\
\text { precursor ( } H \text {. sapiens) }\end{array}$ & T62968 & $\begin{array}{l}\text { Cell surface receptor-linked signal } \\
\text { transduction, cell death, } \\
\text { oncogenesis }\end{array}$ & $\begin{array}{l}\text { Cell surface receptor-linked } \\
\text { signal transduction }\end{array}$ \\
\hline CCNG1 & Cyclin G1 & R45687 & Cell death, cell cycle, oncogenesis & Cell cycle, cell death \\
\hline CDKN1C & $\begin{array}{l}\text { Cyclin-dependent kinase inhibitor } \\
\text { 1C (p57, Kip2) }\end{array}$ & R81336 & Cel cycle, oncogenesis & Cell cycle, cell proliferation \\
\hline \multirow[t]{2}{*}{ GRIA1 } & $\begin{array}{l}\text { Glutamate receptor, ionotropic, } \\
\text { AMPA } 1\end{array}$ & N47974 & $\begin{array}{l}\text { Developmental processes, cell } \\
\text { surface receptor-linked signal } \\
\text { transduction, cell death }\end{array}$ & $\begin{array}{l}\text { Cell death, cell surface } \\
\text { receptor-linked signal } \\
\text { transduction }\end{array}$ \\
\hline & $\begin{array}{l}\text { Homo sapiens mRNA for KIAA1888 } \\
\text { protein, partial cds }\end{array}$ & H26264 & $\begin{array}{l}\text { Transport, cell surface } \\
\text { receptor-linked signal } \\
\text { transduction, cell death, } \\
\text { intracellular signaling cascade }\end{array}$ & Transport \\
\hline$F M O D$ & Fibromodulin & AA029408 & $\begin{array}{l}\text { Transport, cell adhesion, cell } \\
\text { organization and biogenesis, cell } \\
\text { surface receptor-linked signal } \\
\text { transduction, cell cycle }\end{array}$ & Cell adhesion \\
\hline CDK5R1 & $\begin{array}{l}\text { Cyclin-dependent kinase } 5, \\
\text { regulatory subunit } 1 \text { (p35) }\end{array}$ & R49183 & $\begin{array}{l}\text { Cell proliferation, lipid metabolism, } \\
\text { cell cycle }\end{array}$ & Cell proliferation, cell cycle \\
\hline \multirow[t]{3}{*}{ CAT } & Catalase & W89002 & $\begin{array}{l}\text { Stress response, transcription, } \\
\text { oncogenesis }\end{array}$ & Stress response \\
\hline & $\begin{array}{l}\text { Homo sapiens, clone MGC: } 16131 \\
\text { IMAGE: } 3628944, \text { mRNA, } \\
\text { complete cds }\end{array}$ & R71462 & $\begin{array}{l}\text { Transport, intracellular signaling } \\
\text { cascade }\end{array}$ & $\begin{array}{l}\text { Transport, intracellular signaling } \\
\text { cascade }\end{array}$ \\
\hline & $\begin{array}{l}\text { ESTs, moderately similar to JX0336 } \\
\text { succinate dehydrogenase } \\
\text { (H. sapiens) }\end{array}$ & R60996 & $\begin{array}{l}\text { Lipid metabolism, intracellular } \\
\text { signaling cascade, energy } \\
\text { pathways }\end{array}$ & $\begin{array}{l}\text { Energy pathways, lipid } \\
\text { metabolism }\end{array}$ \\
\hline GBAS & Glioblastoma amplified sequence & T90846 & $\begin{array}{l}\text { Lipid metabolism, cell surface } \\
\text { receptor-linked signal } \\
\text { transduction }\end{array}$ & $\begin{array}{l}\text { Cell surface receptor-linked } \\
\text { signal transduction }\end{array}$ \\
\hline
\end{tabular}

Reclassifications for some of the known genes in the data set are shown. A full record of reclassifications for all known genes is provided in Supplemental Material (available online at http://www.genome.org).

were frequently annotated to the same gene. This indicated that these processes are also related in the sense that they involve proteins that are known to participate in both processes. Consequently, our model rediscovered several pairs of processes that are also linked by coannotations. Additionally, the model discovered transcriptional coregulation of pairs of biological processes that do not involve high numbers of genes known to participate in both processes, such as transcription-intracellular signaling cascade and transcription-lipid metabolism. These pairs of processes show a low dependency between coannotations and coclassifications to the same gene (Table 8). Our results indicate that in each of these pairs the biological processes follow similar time courses even though each of the processes is mainly carried out by proteins not directly involved in the other process of the pair. The processes transcription and lipid metabolism are not known to cooperate in a general sense even though lipid metabolism is partly regulated by transcription. However, for the process pair transcription-intracellular signaling cascade, our model has discovered coregulation of genes involved in two processes that are known to cooperate because transcription in most cases is regulated by intracellular signaling cascades.

\section{Use of the Model to Predict Biological Roles of Unknown Genes}

We obtained a total of 548 classifications for 211 genes out of the 213 unknown (uncharacterized) genes (Table 9). These 
Table 7. False Positives for oncogenesis: Missing Annotations

\begin{tabular}{|c|c|c|c|c|}
\hline $\begin{array}{l}\text { Symbol (GenBank } \\
\text { accession number) }\end{array}$ & Gene name & Molecular function & Comment & Reference (PMID) \\
\hline CCNG1 (R45687) & Cyclin G1 & CDK kinase regulator & p53 target & 11327114 \\
\hline CDKN1C (R81336) & $\begin{array}{l}\text { Cyclin-dependent kinase } \\
\text { inhibitor } 1 \mathrm{C}\end{array}$ & $\begin{array}{l}\text { Cyclin-dependent protein } \\
\text { kinase inhibitor }\end{array}$ & Tumor suppressor & 7729684 \\
\hline CAT (W89002) & Catalase & Oxidoreductase & Tumor progression & 8513880,11597785 \\
\hline ALDH3A2 (H63779) & Aldehyde dehydrogenase 10 & Aldehyde dehydrogenase & Tumor progression & 92393980 \\
\hline ADD3 (AA054129) & Adducin 3 (gamma) & $\begin{array}{l}\text { Membrane-cytoskeleton- } \\
\text { associated protein }\end{array}$ & Tumor progression & 9607561 \\
\hline TFDP2 (W46792) & $\begin{array}{l}\text { Transcription factor Dp-2 (E2F } \\
\quad \text { dimerization partner 2) }\end{array}$ & Transcription cofactor & Cell cycle regulation & 7784053 \\
\hline ATRX (N22858) & $\begin{array}{l}\alpha \text { Thalassemia/mental } \\
\text { retardation syndrome }\end{array}$ & DNA helicase & $\begin{array}{l}\text { Transcription and } \\
\text { DNA repair }\end{array}$ & 10362365,10630641 \\
\hline EPS15 (N78949) & $\begin{array}{l}\text { Epidermal growth factor } \\
\text { receptor pathway substrate } \\
15\end{array}$ & Kinase substrate & Growth regulation & 93361014 \\
\hline EGR1 (H27557) & Early growth response 1 & Transcription factor & Tumor suppressor & 9109500 \\
\hline NR4A2 (N22386) & $\begin{array}{l}\text { Nuclear receptor subfam 4, } \\
\text { group A, m2 (Nurr1, Not) }\end{array}$ & $\begin{array}{l}\text { Ligand-dependent nuclear } \\
\text { receptor }\end{array}$ & Proto-oncogene & 9592180 \\
\hline NR4A3 (W42606) & $\begin{array}{l}\text { Nuclear receptor subfam } 4, \\
\text { group A, m } 3 \text { (Nor1) }\end{array}$ & $\begin{array}{l}\text { Ligand-dependent nuclear } \\
\text { receptor }\end{array}$ & Proto-oncogene & 9592180 \\
\hline COPEB (AA055585) & $\begin{array}{l}\text { Core promotor } \\
\text { element-binding protein }\end{array}$ & Transcription factor & Proto-oncogene & 9268646 \\
\hline
\end{tabular}

This table shows genes classified but not annotated with the biological process oncogenesis (e.g., false positives for oncogenesis), where information could be found in the literature confirming that the classification was correct and thus represented knowledge that was missed during annotation (missing annotation).

classifications should be regarded as hypotheses about the biological roles of these genes. The quality of such predictions is estimated using cross-validation over the training examples (known genes; Table 4). We also searched for homology information that could be used to make assumptions about the biological processes in which the uncharacterized genes may participate. Of the 24 genes for which such assumptions could be made, 11 genes had one or more classifications that matched this assumption (Table 10). These genes include LOC55977, which shows some homology to the thromboxane A-2 receptor known to be involved in the LOC55977classified processes blood coagulation (Halushka et al. 1995) and in developmental processes (development of the retina; Hardy et al. 2000). FLJ10217, homologous to oxysterolbinding protein, was classified with cell death and blood coagulation, which are biological processes in which oxysterolbinding protein is known to participate (Schroepfer Jr. 2000). $H$-l(3)mbt-l is a human homolog of a Drosophila tumorsuppressor protein (Koga et al. 1999) involved in chromosome segregation and was classified with the processes cell proliferation and oncogenesis. An EST, highly similar to SMHU1B metallothionein $1 \mathrm{~B}$, was classified with the processes ion homeostasis and stress response, which are the biological processes annotated to metallothioneins (Davis and Cousins 2000).

\section{DISCUSSION}

Supervised learning methods in the analysis of gene expression offer a complementary approach to unsupervised methods such as cluster analysis. Instead of first discovering new classes of expression-wise related genes and then evaluating them according to known classes of biological process, this approach builds models from training examples of genes previously known to be involved in specific biological processes and uses the models both for reclassification of the known genes and for classification of uncharacterized genes.
The annotation process provides a link between biological knowledge and gene expression profiles. Our method handles multiple annotations and multiple classifications, which is important because there are many genes that encode proteins that play a role in more than one biological process. The learning examples are very complex also from a different perspective: Although genes that constitute one class (e.g., a GO biological process) are biologically related, their corresponding temporal expression profiles can be very different including, for instance, inverse coregulation or coregulation with a time lag or a combination of both (see Figs. 1 and 3). Our method accommodates this complexity of temporal gene expression profiles by focusing on relative changes in gene transcript profiles over shorter time intervals. With a supervised learning approach, we can use the learning examples to find characteristic properties (features) of each class, which are given a priori "increasing", "decreasing", "constant", and GO annotations, and then use these features in model construction. Our results therefore demonstrate how supervised methods may contribute in generating hypotheses about gene biological roles. Establishing the optimal supervised learning method for biological role classification from gene expressions was not among the aims of this work, and it is possible that other supervised approaches and systems might be used with comparable success.

The legible nature of if-then rules makes our approach particularly suitable for practical application in gene expression analysis because biologists can inspect the rules and get a clear intuition about how the approach works. This is opposed to, for example, neural networks and support vector machines. Of course, large rule sets are still difficult to comprehend, and methods for rule pruning and graphical displaying still have to be developed further. Also, other supervised methods produce legible models, such as decision trees. Decision trees, however, select features individually by ranking them, whereas our approach considers the discriminatory ca- 
Table 8. Pairs of Biological Processes With High Frequency of Coclassifications to the Same Gene

\begin{tabular}{|c|c|c|c|c|c|c|}
\hline Pairs of processes & $\begin{array}{c}\text { A } \\
\text { Genes with } \\
\text { coclassification }\end{array}$ & $\begin{array}{c}\text { B } \\
\text { Genes with } \\
\text { coclassification } \\
\text { and coannotation }\end{array}$ & $\begin{array}{c}\text { C } \\
\text { Genes with } \\
\text { coclassification, } \\
\text { but no } \\
\text { coannotation }\end{array}$ & $\begin{array}{c}\text { D } \\
\text { Genes with } \\
\text { coannotation } \\
\text { but no } \\
\text { coclassification }\end{array}$ & $\begin{array}{c}\text { E } \\
\text { Genes without } \\
\text { coclassification } \\
\text { and } \\
\text { coannotation }\end{array}$ & $\underset{P \text {-value }}{\mathrm{F}}$ \\
\hline DNA metabolism-cell cycle & 25 & 12 & 13 & 0 & 219 & 7.36E-14 \\
\hline Transcription-oncogenesis & 22 & 5 & 17 & 2 & 220 & $7.08 \mathrm{E}-05$ \\
\hline \multicolumn{7}{|l|}{ Cell organization and } \\
\hline biogenesis-cell cycle & 18 & 13 & 5 & 3 & 223 & $3.58 \mathrm{E}-15$ \\
\hline Transcription-cell proliferation & 18 & 10 & 8 & 2 & 224 & $1.59 \mathrm{E}-11$ \\
\hline Transcription-cell cycle & 18 & 7 & 11 & 2 & 224 & $1.13 \mathrm{E}-07$ \\
\hline \multicolumn{7}{|l|}{ Cell motility-defense (immune) } \\
\hline response & 16 & 11 & 5 & 2 & 226 & $9.00 \mathrm{E}-14$ \\
\hline DNA metabolism-transcription & 15 & 9 & 6 & 1 & 228 & $6.72 \mathrm{E}-12$ \\
\hline Oncogenesis-cell proliferation & 14 & 5 & 9 & 3 & 227 & $1.47 \mathrm{E}-05$ \\
\hline \multicolumn{7}{|l|}{ Defense (immune) } \\
\hline response-cell proliferation & 13 & 7 & 6 & 4 & 227 & $5.52 \mathrm{E}-08$ \\
\hline \multicolumn{7}{|l|}{ Transcription-intracellular } \\
\hline Cell motility-cell adhesion & 12 & 10 & 2 & 1 & 231 & $4.21 \mathrm{E}-15$ \\
\hline Protein metabolism and & 12 & 5 & 7 & 0 & ב2 & 115507 \\
\hline \multicolumn{7}{|l|}{$\begin{array}{l}\text { Protein metabolism and } \\
\text { modification-cell }\end{array}$} \\
\hline organization and biogenesis & 11 & 6 & 5 & 0 & 233 & $1.68 \mathrm{E}-09$ \\
\hline Cell motility-cell proliferation & 11 & 6 & 5 & 2 & 231 & 4.53E-08 \\
\hline Cell proliferation-intracellular & & 1 & & 1 & $22+>$ & \\
\hline Transcription-lipid metabolism & 11 & $\begin{array}{l}4 \\
1\end{array}$ & 10 & $\begin{array}{l}1 \\
0\end{array}$ & $\begin{array}{l}232 \\
233\end{array}$ & $\begin{array}{l}1.12 \mathrm{E}-05 \\
4.51 \mathrm{E}-02\end{array}$ \\
\hline
\end{tabular}

pability of several features combined. This might prove advantageous in biological applications, although it comes with a price of higher computational demands (the time consumed by the algorithm grows proportional to the square of the number of examples). Whereas most supervised learning algorithms use expression ratios directly, our Rough Set-based approach requires discrete values. Several algorithms for discretization exist, but finding something that works can quite often be a difficult task. Being able to handle discrete values, however, can be advantageous in biological application because, for example, sequence-derived data may easily be added as a part of the basis for inducing models.

The results demonstrate that our method is robust. Even training example genes with incomplete annotations may be used for learning. Many false-positive reclassifications for the known genes were found to represent true knowledge. Existing knowledge that had not been included in the annotation process could now be found by a literature search guided by the hypotheses generated by our model. This illustrates how the training examples may be updated through a reclassification process. It follows that an enhanced model may be obtained from the iteratively improved (and validated) annotations of the genes used as examples for learning.

A considerable proportion of hypotheses generated for unknown genes agreed with assumptions based on homology information available for a small number of these genes. This confirms the cross-validation estimates, suggesting that hy- potheses produced for unknown genes are of high quality. The hypotheses created by our classification process should be validated experimentally. However, this task was outside the scope of the present work.

Few clustering studies provide a quantitative measure of the agreement between clusters and biological categories. Thus, most clustering studies cannot specify to which degree we can trust assignment of biological role to uncharacterized genes in these clusters. Cho et al. (2001) used a semisupervised method in which class knowledge was used to help find clusters in an analysis of gene expression profiles during human fibroblast cell cycle. Hypothesis testing was used to determine whether biologically related genes were statistically overrepresented in the expression clusters. Although Cho et al. did not explore the possible use of their clusters for classification of genes, this has recently been reported by Wu et al. (2002) using a similar semisupervised methodology. Statistically significant overlapping clusters were annotated with biological process and subsequently used for prediction of the involvement of 1644 of 3020 uncharacterized yeast genes. Because the clusters were overlapping, one gene could be predicted to several processes. Validation on known genes showed that the method could provide high-quality classifications for some of the processes represented in the training set.

To the best of our knowledge, Brown et al. (2000) have done the only study in which the biological roles of genes are 
Lægreid et al.

Table 9. Classification of Uncharacterized Genes

\begin{tabular}{|c|c|c|c|}
\hline Gene symbol & Gene name & $\begin{array}{c}\text { GenBank } \\
\text { accession number }\end{array}$ & $\begin{array}{l}\text { Predictions for the } 23 \text { broad } \\
\text { cellular processes used for learning }\end{array}$ \\
\hline LOC80298 & Transcription termination factor-like protein & W95909 & $\begin{array}{l}\text { Cell surface receptor-linked signal } \\
\text { transduction, cell cycle }\end{array}$ \\
\hline \multirow[t]{2}{*}{$E S T$, unclustered } & & AA044605 & $\begin{array}{l}\text { Protein metabolism and modification, } \\
\text { developmental processes }\end{array}$ \\
\hline & ESTs & AA059077 & $\begin{array}{l}\text { Cell proliferation, protein metabolism and } \\
\text { modification, cell motility, } \\
\text { developmental processes }\end{array}$ \\
\hline$E S T$, unclustered & & AA035657 & $\begin{array}{l}\text { Protein metabolism and modification, } \\
\text { developmental processes }\end{array}$ \\
\hline \multirow[t]{2}{*}{ KIAA0455 } & KIAA0455 gene product & H19324 & Cell death, blood coagulation \\
\hline & $\begin{array}{l}\text { Homo sapiens cDNA FLJ13545 fis, clone } \\
\text { PLACE1006867 }\end{array}$ & W89018 & Lipid metabolism \\
\hline \multirow[t]{3}{*}{ KIAA1391 } & KIAA1391 protein & $\mathrm{H} 28360$ & $\begin{array}{l}\text { Cell surface receptor-linked signal } \\
\text { transduction, transcription }\end{array}$ \\
\hline & ESTs & H16592 & Cell motility, cell death \\
\hline & ESTs & W78151 & Cell death, blood coagulation \\
\hline \multirow[t]{3}{*}{$E S T$, unclustered } & & H14500 & Cell death \\
\hline & Homo sapiens clone 23645 mRNA sequence & N75026 & Cell death, blood coagulation \\
\hline & $\begin{array}{l}\text { Homo sapiens cDNA: FLJ21482 fis, clone } \\
\text { COL05135 }\end{array}$ & R87731 & Cell death, blood coagulation \\
\hline \multirow[t]{4}{*}{$E S T$, unclustered } & & H61274 & Cell death, blood coagulation \\
\hline & $\begin{array}{l}\text { Homo sapiens mRNA; cDNA DKFZp761K2024 } \\
\text { (from clone DKFZp761K2024) }\end{array}$ & N63445 & Cell death, blood coagulation \\
\hline & $\begin{array}{l}\text { Homo sapiens mRNA; cDNA DKFZp564L0822 } \\
\text { (from clone DKFZp564L0822) }\end{array}$ & W69445 & $\begin{array}{l}\text { Cell surface receptor-linked signal } \\
\text { transduction, cell death, blood } \\
\text { coagulation }\end{array}$ \\
\hline & $\begin{array}{l}\text { Homo sapiens mRNA; cDNA DKFZp58611823 } \\
\text { (from clone DKFZp58611823) }\end{array}$ & R60336, H15535 & Lipid metabolism, transcription \\
\hline KIAA1628 & KIAA1628 protein & N53427 & Lipid metabolism transcription \\
\hline FLJ20643 & $\begin{array}{l}\text { ESTs } \\
\text { Hypothetical protein FLJ20643 }\end{array}$ & $\begin{array}{l}\text { R60731 } \\
\text { AA018444 }\end{array}$ & $\begin{array}{l}\text { Lipid metabolism transcription } \\
\text { Cell death, blood coagulation, } \\
\text { oncogenesis }\end{array}$ \\
\hline KIAA0993 & KIAA0993 protein & AA031778 & $\begin{array}{l}\text { Cell surface receptor-linked signal } \\
\text { transduction, transcription, oncogenesis }\end{array}$ \\
\hline$E S T$, unclustered & & W86006 & $\begin{array}{l}\text { Cell proliferation, lipid metabolism, cell } \\
\text { adhesion, developmental processes, } \\
\text { blood coagulation }\end{array}$ \\
\hline
\end{tabular}

Classifications for some of the uncharacterized genes in the data set are shown. A full record of classifications of all unknown genes is provided in Supplemental Material (available on line at http://www.genome.org).

classified from expression data in a supervised manner. They used 2467 annotated yeast genes to train support vector machines to recognize six different classes of biological roles containing 230 of the 2467 genes. Five of these classes had earlier been shown to exhibit homogenous temporal expression profiles using hierarchical clustering (Eisen et al. 1998), but for the last class this was not true. They then used the model to provide hypotheses on the biological roles for 15 uncharacterized genes.

In our study, 23 different biological process classes with 273 of the 284 known genes were used to train a model. These classes were not selected according to their suitability toward learning; the only requirement was that the class contained at least 4 annotated genes. We may thus claim that our method is close to giving a complete classifier for genes involved in a biological response such as the fibroblast serum response.

Finally, our work shows that Gene Ontology (The Gene Ontology Consortium 2000) emulates biological knowledge that may be associated with gene expression profiles. These associations may be effectively used in discovering new biological roles of unknown and known genes. Future research will include full use of the hierarchy of biological processes given by GO (Midelfart et al. 2001).

\section{METHODS}

\section{Annotation Sources}

The Gene Ontology version used for annotations was revision 1.1152 released August 25, 2000. Annotations used to represent the 23 classes for learning were according to revision 2.158 released December 4, 2001. Unigene data were from build \#145 released in 2001. All homology data were taken from this Unigene build. SWISS-PROT, LocusLink, and GENATLAS data were mainly from the database versions of January 2001 with some occasional newer entries used for some annotations.

\section{The Rule Model}

\section{Data}

The initial gene expression data (Iyer et al. 1999; http:// genome-www.stanford.edu/serum) consisted of expression level ratios for 497 differentially expressed genes measured at 12 time points during the serum response. The ratios were 
Table 10. Uncharacterized Genes With Classifications That Match Biological Functions Deduced From Homology Information

\begin{tabular}{|c|c|c|c|c|}
\hline $\begin{array}{l}\text { Symbol (GenBank } \\
\text { accession number) }\end{array}$ & Gene name & Homology information & Classification & $\begin{array}{l}\text { Classification } \\
\text { matching assumed } \\
\text { biological process } \\
\text { (PMID reference) }\end{array}$ \\
\hline $\begin{array}{l}\text { LOC55977 } \\
\text { (AA037007) }\end{array}$ & $\begin{array}{l}\text { Hypothetical protein } \\
24636\end{array}$ & $\begin{array}{l}\text { Homo sapiens } \\
\text { thromboxane A-2 } \\
\text { receptor, } 53 \% / 55 \text { aa }\end{array}$ & $\begin{array}{l}\text { Protein metabolism and } \\
\text { modification, lipid } \\
\text { metabolism, } \\
\text { developmental } \\
\text { processes, blood } \\
\text { coagulation }\end{array}$ & $\begin{array}{c}\text { Developmental processes } \\
(10963722) \text { blood } \\
\text { coagulation (8777579) }\end{array}$ \\
\hline $\begin{array}{l}\text { FLJ10217 } \\
\text { (W721889) }\end{array}$ & $\begin{array}{l}\text { Oxysterol-binding } \\
\text { protein-related protein } 1\end{array}$ & $\begin{array}{l}\text { H. sapiens } \\
\text { oxysterol-binding } \\
\text { protein, } 36 \% / 711 \text { aа }\end{array}$ & $\begin{array}{l}\text { Cell death, blood } \\
\text { coagulation }\end{array}$ & $\begin{array}{l}\text { Cell death }(10617772) \\
\text { blood coagulation } \\
(10617772)\end{array}$ \\
\hline WW45 (H25014) & $\begin{array}{l}\text { WW domain-containing } \\
\text { gene }\end{array}$ & WW domain & $\begin{array}{l}\text { Cell surface } \\
\text { receptor-linked signal } \\
\text { transduction, } \\
\text { transcription }\end{array}$ & Transcription (11223034) \\
\hline PIST (N68337) & $\begin{array}{l}\text { PDZ/coiled-coil } \\
\text { domain-binding partner } \\
\text { for the rho-family } \\
\text { GTPase TC10 }\end{array}$ & $\begin{array}{l}\text { Mus musculus syntrophin, } \\
43 \% / 110 \text { aа }\end{array}$ & $\begin{array}{l}\text { Stress response, protein } \\
\text { metabolism and } \\
\text { modification, cell } \\
\text { surface receptor-linked } \\
\text { signal transduction, } \\
\text { transcription }\end{array}$ & $\begin{array}{l}\text { Stress response } \\
\quad(10212242,10797403)\end{array}$ \\
\hline ESTs (N33510) & $\begin{array}{l}\text { ESTs, weakly similar to a } \\
\text { chain A, human } \\
\text { Cd69-trigonal } \\
\text { form (SUB 82-199 } \\
\text { (H. sapiens) }\end{array}$ & $\begin{array}{l}\text { H. sapiens cd69, 52\%/37 } \\
\text { aa }\end{array}$ & $\begin{array}{l}\text { Cell surface } \\
\text { receptor-linked signal } \\
\text { transduction, cell cycle, } \\
\text { transcription }\end{array}$ & $\begin{array}{l}\text { Cell surface } \\
\text { receptor-linked signal } \\
\text { transduction } \\
(11092246)\end{array}$ \\
\hline $\begin{array}{l}\text { PTGFRN } \\
\quad(\mathrm{AA045111)}\end{array}$ & $\begin{array}{l}\text { Prostaglandin F2 receptor } \\
\text { negative regulator }\end{array}$ & $\begin{array}{l}\text { Ortholog of Ratius } \\
\text { norvegicus prostaglandin } \\
\text { F2 receptor negative } \\
\text { regulator (http://www. } \\
\text { ncbi.nlm.nih.gov/ } \\
\text { HomoloGene/ } \\
\text { homol.cgi) }\end{array}$ & Transcription, oncogenesis & Oncogenesis (11090944) \\
\hline $\begin{array}{l}H-I(3) m b t-I \\
\quad \text { (AA026761) }\end{array}$ & $\mathrm{H}-\mathrm{I}(3) \mathrm{mbt}$-like protein & $\begin{array}{l}\text { Drosophila melanogaster } \\
\text { T13797 tumor } \\
\text { suppressor protein, } \\
46 \% / 176 \text { aa }\end{array}$ & $\begin{array}{l}\text { Cell proliferation, lipid } \\
\text { metabolism, } \\
\text { transcription, } \\
\text { oncogenesis }\end{array}$ & $\begin{array}{l}\text { Cell proliferation, } \\
\text { oncogenesis } \\
(10445843)\end{array}$ \\
\hline $\begin{array}{l}\text { LOC57018 } \\
\quad(A A 016305)\end{array}$ & Cyclin L ania-6a & $\begin{array}{l}\text { H. sapiens cyclin K, } \\
27 \% / 363 \text { aа }\end{array}$ & $\begin{array}{l}\text { Cell proliferation, } \\
\text { transcription, } \\
\text { oncogenesis }\end{array}$ & $\begin{array}{l}\text { Cell proliferation, } \\
\text { transcription (9632813) }\end{array}$ \\
\hline $\begin{array}{l}\text { HMGE } \\
\quad(\text { AA037156) }\end{array}$ & $\begin{array}{l}\text { GrpE-like protein } \\
\text { cochaperone }\end{array}$ & $\begin{array}{l}\text { Escherichia coli heat shock } \\
\text { protein grpE, } 32 \% / 178 \\
\text { aa }\end{array}$ & $\begin{array}{l}\text { Stress response, protein } \\
\text { metabolism and } \\
\text { modification }\end{array}$ & $\begin{array}{l}\text { Stress response, protein } \\
\text { metabolism and } \\
\text { modification } \\
(10791710)\end{array}$ \\
\hline G2 (R16047) & G2 protein & $\begin{array}{l}\text { H. sapiens G01449 } \\
\text { probable mucin, } \\
100 \% / 1691 \text { aa }\end{array}$ & $\begin{array}{l}\text { Cell adhesion, cell cycle, } \\
\text { DNA metabolism, } \\
\text { protein targeting }\end{array}$ & Cell adhesion (1412714) \\
\hline (H72723) & $\begin{array}{l}\text { ESTs, highly similar to } \\
\text { SMHU1B } \\
\text { metallothionein 1B } \\
\text { (H. sapiens) }\end{array}$ & $\begin{array}{l}\text { H. sapiens SMHU1B } \\
\text { metallothionein 1B, } \\
98 \% / 60 \text { aa }\end{array}$ & $\begin{array}{l}\text { Stress response, protein } \\
\text { metabolism and } \\
\text { modification, ion } \\
\text { homeostasis }\end{array}$ & $\begin{array}{l}\text { Stress response, ion } \\
\text { homeostasis } \\
(10801901)\end{array}$ \\
\hline
\end{tabular}

This table shows the 11 out of 24 uncharacterized genes for which homology information could be found that allowed assumptions concerning functional classification of the gene, and one or more of the homology-based annotations matched the predicted (classified) biological process function.

$\log _{2}$-transformed, and the moving average transformation $t_{i}=\left(t_{i}-t_{i-1}\right) / 2$ was used to smoothen out spikes because such spikes often are artifacts and easily influence the template language used to describe the time profiles.

\section{Feature Synthesis}

To enable focus on relative changes in gene transcript levels over subintervals of the biological response, the expression data were transformed using three templates, "increase", "decrease", and "constant" over time intervals of at least three or four time points (see supplemental Table 11). The "increase/ decrease" templates required a $\log _{2}$ ratio increase/decrease of at least 0.6 over at least three consecutive time points. The template "constant" required a maximum $\log _{2}$ ratio deviation from the mean value smaller than 0.2 over at least four consecutive time points. The parameter values were selected to optimize classification quality over several cross-validation trials in terms of average AUC over all classes and all trials (different cross-validation trials were produced by randomly dividing the data into different training and test sets). A different trial was run to produce the final cross-validation estimates in Table 4 . Hence, reasonably realistic estimates were 
produced without using a separate test set for fine-tuning algorithmic parameters.

\section{Training the Rule Model}

The rule model was trained from examples of templatetransformed expression profiles annotated with biological process using a Rough Set-based framework for rule induction. The concept of the method was originally introduced in Hvidsten et al. (2001). The present version used ROSETTA kernel version 1.0.1 and was further developed to meet the requirements of knowledge discovery in molecular biology. Rough Set theory (Pawlak 1991; Komorowski 1999; Skowron et al. 2002) constitutes a mathematical framework for inducing minimal decision rules (if-then rules) from examples. The general idea is to use Boolean reasoning to obtain minimal sets of features with the same discriminatory properties as the full set of features. The problem of finding such minimal sets, called reducts, is computationally very demanding and is known to be in the class of so-called NP-hard problems. We therefore used genetic algorithms to find approximate reducts that only preserve the discriminatory properties for a large fraction of the examples. Such approximate reducts may provide better classification rules as they tend to avoid the pitfalls of overtraining, that is, of being too specific and thus not being able to classify related but not identical cases. The reducts are used to generate if-then rules that associate a minimal number of characteristic features with a particular class. A large number of such rules put together constitutes a model capable of predicting the class(es) of an unknown gene based solely on its expression profile. Predictions are obtained by letting each rule matching the example to be classified cast a number of votes in favor of the biological process modeled by this rule. The number of votes is proportional to the support of the rule (i.e., the number of examples annotated with the process in the right-hand side of the rule that also has a time profile that matches the left-hand side of the rule). Classifications are selected among the processes that have a higher fraction of votes than an experimentally chosen selection threshold available for each class.

\section{Validation of the Model}

A 10-fold cross-validation over the training examples was used to assess the classification quality of the method. This corresponds to dividing the set of training examples randomly into 10 nonoverlapping equally sized subsets. One subset is used for testing, whereas the others are used to train a model. This is repeated 10 times so that each subset is a test set once and a part of the training set 9 times. The crossvalidation performance estimates constitute the average classification quality of each submodel on the 10 test sets. In Table 4 we report the area under the ROC curve (AUC) for each biological process. AUC is an estimate of the discriminatory power of the classifier independent of the threshold values. When unseen cases are classified, we need to choose fixed thresholds. Sensitivity and specificity for the "best" selection thresholds according to some optimization criterion are shown in Table 4 . Using these thresholds, $84 \%$ of all annotations for the training examples could be classified correctly (sensitivity). Of all classifications, 49\% were correct. Using a stricter criterion (higher selection thresholds) enabled us to increase the fraction of correct classifications to $>90 \%$, with a corresponding drop in sensitivity to $39 \%$.

All computations were done using the ROSETTA toolkit kernel version 1.0.1 (Komorowski et al. 2002) for Rough Set analysis.

\section{ACKNOWLEDGMENTS}

The contributions of Dag Kristian Rognlien, Vladimir Yankovski, Dyre Tjeldvoll, and Tor-Kristian Jenssen to the annotation process are greatly appreciated. We also thank Mette
Langaas for valuable advice and assistance in statistical analysis.

The publication costs of this article were defrayed in part by payment of page charges. This article must therefore be hereby marked "advertisement" in accordance with 18 USC section 1734 solely to indicate this fact.

\section{REFERENCES}

Adachi, Y. and Yanagida, M. 1989. Higher order chromosome structure is affected by cold-sensitive mutations in a Schizosaccharomyces pombe gene crm1+ which encodes a $115-\mathrm{kD}$ protein preferentially localized in the nucleus and its periphery. J. Cell Biol. 108: 1195-1207.

Brown, M.P., Grundy, W.N., Lin, D., Cristianini, N., Sugnet, C.W., Furey, T.S., Ares Jr., M., and Haussler, D. 2000. Knowledge-based analysis of microarray gene expression data by using support vector machines. Proc. Natl. Acad. Sci. 97: 262-267.

Cho, R.J., Huang, M., Campbell, M.J., Dong, H., Steinmetz, L., Sapinoso, L., Hampton, G., Elledge, S.J., Davis, R.W., and Lockhart, D.J. 2001. Transcriptional regulation and function during the human cell cycle. Nat. Genet. 27: 48-54.

Davis, S.R. and Cousins, R.J. 2000. Metallothionein expression in animals: A physiological perspective on function. J. Nutr. 130: $1085-1088$.

Eisen, M.B., Spellman, P.T., Brown, P.O., and Botstein, D. 1998. Cluster analysis and display of genome-wide expression patterns. Proc. Natl. Acad. Sci. 95: 14863-14868.

Everitt, B.S. 1992. The analysis of contingency tables. In Monographs on statistics and applied probability, 2nd ed. vol. 45, pp. 1-164. Chapman \& Hall, London, UK.

The Gene Ontology Consortium (Ashburner, M., Ball, C.A., Blake, J.A., Botstein, D., Butler, H., Cherry, J.M., Davis, A.P., Dolinski, K., Dwight, S.S., Eppig, J.T., et al.). 2000. Gene ontology: Tool for the unification of biology. Nat. Genet. 25: 25-29.

Halushka, P.V., Allan, C.J., and Davis-Bruno, K.L. 1995. Thromboxane A2 receptors. J. Lipid Mediat. Cell Signal. 12: $361-378$

Hardy, P., Dumont, I., Bhattacharya, M., Hou, X., Lachapelle, P., Varma, D.R., and Chemtob, S. 2000. Oxidants, nitric oxide and prostanoids in the developing ocular vasculature: A basis for ischemic retinopathy. Cardiovasc. Res. 47: 489-509.

Hvidsten, T.R., Komorowski, J., Sandvik, A.K., and Lægreid, A. 2001 Predicting gene function from gene expressions and ontologies. Pac. Symp. Biocomput. (eds. R.B. Altman et al.) pp. 299-310. World Scientific Publishing, Singapore.

Iyer, V.R., Eisen, M.B., Ross, D.T., Schuler, G., Moore, T., Lee, J.C., Trent, J.M., Staudt, L.M., Hudson Jr., J., Boguski, M.S., et al. 1999. The transcriptional program in the response of human fibroblasts to serum. Science 283: 83-87.

Koga, H., Matsui, S., Hirota, T., Takebayashi, S., Okumura, K., and Saya, H. 1999. A human homolog of Drosophila lethal(3)malignant brain tumor (1(3)mbt) protein associates with condensed mitotic chromosomes. Oncogene 18: 3799-3809.

Komorowski, J. 1999. Rough Sets-A tutorial. In Rough-fuzzy hybridization-A new trend in decision making (eds. S.K. Pal and A. Skowron), pp. 3-98. Singapore Pte Ltd., Springer Verlag, Singapore.

Komorowski, J., Skowron, A., and Øhrn, A. 2002. ROSETTA Rough Set software system. In Handbook of data mining and knowledge discovery (eds. W. Kløsgen and J. Zytkow), pp. 554-559. Oxford University Press, New York, NY.

Midelfart, H., Lægreid, A., and Komorowski, J. 2001. Classification of gene expression data in an ontology. In International Symposium on Medical Data Analysis (eds. J. Crespo et al.), pp. 186-194. Springer-Verlag, Vienna, Austria.

Pawlak, Z. 1991. Rough Sets. Theory Decision Lib. 9: 1-229.

Ravnik, S.E. and Wolgemuth, D.J. 1996. The developmentally restricted pattern of expression in the male germ line of a murine cyclin A, cyclin A2, suggests roles in both mitotic and meiotic cell cycles. Dev. Biol. 173: 69-78.

Schena, M., Shalon, D., Davis, R.W., and Brown, P.O. 1995. Quantitative monitoring of gene expression patterns with a complementary DNA microarray. Science 270: 467-470.

Schroepfer Jr., G.J. 2000. Oxysterols: Modulators of cholesterol metabolism and other processes. Physiol. Rev. 80: 361-554.

Shatkay, H., Edwards, S., Wilbur, W.J., and Boguski, M. 2000. Genes, themes and microarrays: Using information retrieval for 
large-scale gene analysis. Proc. Int. Conf. Intell. Syst. Mol. Biol. 8: $317-328$.

Skowron, A., Komorowski, J., Pawlak, Z., and Polkowski, L. 2002. A Rough Set perspective on data and knowledge. In Handbook of data mining and knowledge discovery (eds. W. Kløsgen and J. Zytkow), pp. 134-149. Oxford University Press, New York, NY.

Stanton, L.W., Garrard, L.J., Damm, D., Garrick, B.L., Lam, A., Kapoun, A.M., Zheng, Q., Protter, A.A., Schreiner, G.F., and White, R.T. 2000. Altered patterns of gene expression in response to myocardial infarction. Circ. Res. 86: 939-945.

Torgo, L. 1993. In Proceedings of the European Conference on Machine Learning (ed. P.B. Brazdil), pp. 185-196. Springer Verlag, Vienna, Austria.

Wu, L.F., Hughes, T.R., Davierwala, A.P., Robinson, M.D., Stoughton, R., and Altschuler, S.J. 2002. Large-scale prediction of Saccharomyces cerevisiae gene function using overlapping transcriptional clusters. Nat. Genet. 31: 255-265.

Zhang, H., Kobayashi, R., Galaktionov, K., and Beach, D. 1995. p19Skp1 and p45Skp2 are essential elements of the cyclin A-CDK2 S phase kinase. Cell 82: 915-925.
Zhu, X., Mancini, M.A., Chang, K.H., Liu, C.Y., Chen, C.F., Shan, B., Jones, D., Yang-Feng, T.L., and Lee, W.H. 1995. Characterization of a novel 350-kilodalton nuclear phosphoprotein that is specifically involved in mitotic-phase progression. Mol. Cell. Biol. 15: 5017-5029.

\section{WEB SITE REFERENCES}

http://bisance.citi2.fr/GENATLAS; GENATLAS.

http://genome-www.stanford.edu/serum; Web supplement to Iyer et al. (1999).

http://us.expasy.org/sprot; SWISS-PROT protein database.

http://www.geneontology.org; Gene Ontology Consortium.

http://www.lcb.uu.se/ hvidsten/fibroblast; author Web site.

http://www.ncbi.nlm.nih.gov/LocusLink/index.html; LocusLink.

http://www.ncbi.nlm.nih.gov/UniGene/index.html; UniGene.

Received June 5, 2002; accepted in revised form January 28, 2003. 


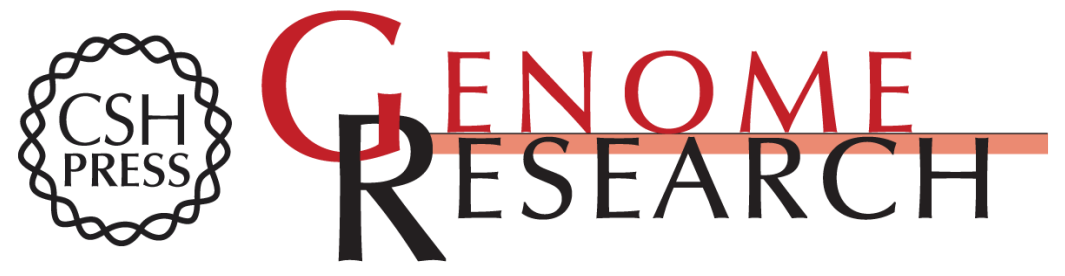

\section{Predicting Gene Ontology Biological Process From Temporal Gene Expression Patterns}

Astrid Lægreid, Torgeir R. Hvidsten, Herman Midelfart, et al.

Genome Res. 2003 13: 965-979

Access the most recent version at doi:10.1101/gr.1144503

Supplemental Material

References License

Email Alerting Service
http://genome.cshlp.org/content/suppl/2003/06/18/GR-11445R.DC1

This article cites 18 articles, 8 of which can be accessed free at: http://genome.cshlp.org/content/13/5/965.full.html\#ref-list-1

Receive free email alerts when new articles cite this article - sign up in the box at the top right corner of the article or click here.

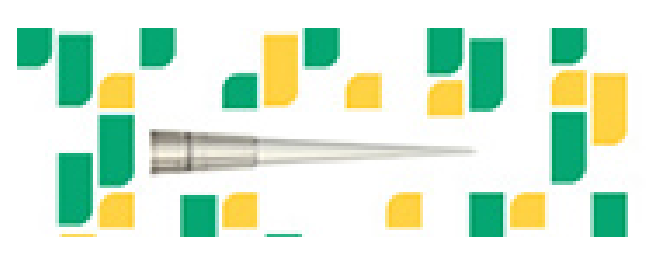

To subscribe to Genome Research go to: https://genome.cshlp.org/subscriptions 